\title{
Distribution of the monthly global solar irradiation in the state of Tabasco, Mexico
}

\author{
Aceves-Navarro, L.A. ${ }^{1}$; Santillán-Fernández, A. ${ }^{2}$; Rivera-Hernández, B. ${ }^{3 *}$; González-Mancillas, R. ${ }^{4}$; \\ Arrieta-Rivera, A. ${ }^{5}$; Gutiérrez-Buron, R. ${ }^{2}$
}

\footnotetext{
${ }^{1}$ Colegio de Postgraduados-Campus Tabasco. Carretera Cárdenas-Huimanguillo km 3.5 Cárdenas, Tabasco, México.

${ }^{2}$ CONACyT-Colegio de Postgraduados, Campus-Campeche. Carretera Federal Haltunchén-Edzná. Sihochac, Champotón, Campeche, México.

${ }^{3}$ Universidad Popular de la Chontalpa. Carretera Cárdenas-Huimanguillo, km 2.0, R/a Pazo y Playa, Cárdenas, Tabasco, México.

${ }^{4}$ Colegio de Postgraduados, Campus Montecillo, Hidrociencias. Texcoco, Estado de México. 5 Instituto Tecnológico de la Zona Olmeca. Prol. Ignacio Zaragoza S/N, Villa Ocuiltzapotlán, Centro, Tabasco, México.

* Corresponding author: benigno.rivera@upch.mx
}

Gitation: Aceves-Navarro, L.A. , SantillánFernández, A., Rivera-Hernández, B., González-Mancillas, R., Arrieta-Rivera, A. \& Gutiérrez-Buron, R. (2021). Distribution of the monthly global solar irradiation in the state of Tabasco, Mexico Agro Productividad, 14(\#). https://doi.org/10.32854/agrop.vl4i7.1863

Editor in Chief: Dr. Jorge Cadena Iñiguez

Estimated publication date: August 2021

This work is licensed under a Creative Commons Attribution-Non-Commercial 4.0 International license.

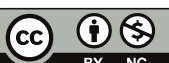

\begin{abstract}
Objective: To estimate the monthly average global solar irradiance $\left(R_{g}\right)$, using observed cloudiness data $(\%$ of cloudy days), as well as its spatial distribution for the state of Tabasco, Mexico.

Design/Methodology/Approximation: The proposed model by Tejeda-Martínez et al. (1999) was adjusted to estimate the $R_{g}$ of 35 meteorological stations in the state of Tabasco. The adjustment was performed with daily observed $R_{g}$ data from eight automated weather stations and cloudiness data from eight ordinary weather stations.

Results: The proposed model reports a good fit, given that its prediction was optimal according to Willmott's comparison parameter $(c=0.89)$, and excellent based on the Nash-Sutcliffe efficiency index $(E=0.99)$ and had a high corrected determination coefficient of $R_{c}^{2}=0.87$.

Study limitations/implications: It is necessary that in the state of Tabasco the number of automated stations increase, as well as technical maintenance to the existing stations.

Findings/conclusions: The estimated $R_{g}$ is statistically reliable. The highest $R_{g}$ values occurred during the dry season, with a maximum of $22.99 \mathrm{MJ} \mathrm{m}^{-2} \mathrm{~d}^{-1}$, distributed mainly in the northern part of the state. The lowest $R_{g}$ values occurred during the northeast season $\left(12.52 \mathrm{MJ} \mathrm{m}^{-2} \mathrm{~d}^{-1}\right)$, distributed in more than $80 \%$ of the total state area.
\end{abstract}

Keywords: Willmott's index, cloud cover, transmissibility, heliophany.

\section{INTRODUCTION}

The information of the spatial and temporal variation of global solar irradiance values $\left(R_{g}\right)$ is of utmost importance to calculate the net primary productivity of plant species (Bouchouicha et al., 2019); as well as for estimating the agricultural crop's potential yield (van Ittersum et al., 2013). In Mexico, as in many areas of the world, $R_{g}$ is historically 
the least recorded meteorological variable (Quej et al., 2016). The $R_{g}$ has to be estimated from empirical models based on other readily available meteorological variables. Detailed knowledge of the spatial and temporal variation of $R_{g}$ is still limited for the state of Tabasco, Mexico, and the southeast of the country because most of the existing meteorological stations are conventional and do not record it. The objective of the present research was to estimate the monthly average global solar irradiance, using observed cloudiness data, to elaborate monthly maps, showing its spatial distribution.

\section{MATERIALS AND METHODS}

\section{Evaluated climatological variables}

Daily data on the percentage of cloudy days (cloudy and medium cloudy days) were obtained from the ERIC III v.2 program from 34 ordinary climatological stations and a meteorological observatory at the state of Tabasco, Mexico (IMTA, 2009). This program allows the extraction of information contained in the CLICOM historical database of the National Meteorological Service (SMN) of Mexico.

Daily global solar irradiance data were obtained from the records of nine automatic meteorological stations (AMS's) of the SMN in Tabasco (SMN, 2016). Daily data were obtained from 2012 to 2015, as these were the most recent and complete. From the daily data of both variables, monthly averages of cloudiness (cloudy and half cloudy days) and global solar irradiance $\left(\boldsymbol{R}_{g}\right)$ in $\left(\mathrm{W} \mathrm{m}^{-2}\right)$ were obtained. The data from each AMS was related to that of an ordinary climatological station that was less than $5 \mathrm{~km}$ away to ensure that the climatic conditions were similar. Table 1 shows the relation of the selected AMS's and their associated ordinary climatological station, from which the $R_{g}$ data and the percentage of cloudy days (cloudiness) were obtained.

Table 1. List of the automatic meteorological stations (AMS) and their associated ordinary climatological station at Tabasco, Mexico.

\begin{tabular}{l|c|c|c|l|c|c|c}
\hline Automatic Weather Station & Lat. & Long. & Alt. & Ordinary weather station & Lat. & Long. & Alt. \\
\hline Boca del Cerro, Tenosique & 17.54 & 91.49 & 14 & Boca de Cerro, Tenosique & 17.43 & 91.32 & 27 \\
\hline Dos Patrias, Tacotalpa & 17.61 & 92.80 & 25 & Dos Patrias, Tacotalpa & 17.61 & 92.80 & 25 \\
\hline E. Zapata, Emiliano Zapata & 17.75 & 91.76 & 20 & E. Zapata, Emiliano Zapata & 17.74 & 91.78 & 26 \\
\hline Huimanguillo, Huimanguillo & 17.85 & 93.40 & 20 & Huimanguillo, Huimanguillo & 17.87 & 93.47 & 36 \\
\hline Paraíso, Paraíso & 18.42 & 93.02 & 4 & Paraíso, Paraíso & 17.97 & 93.22 & 6 \\
\hline Pueblo Nuevo, Centro & 17.87 & 92.87 & 15 & Pueblo Nuevo, Centro & 17.85 & 92.88 & 60 \\
\hline San Pedro, Balancán & 17.77 & 91.03 & 50 & San Pedro, Balancán & 17.79 & 91.16 & 36 \\
\hline Tres Brazos, Centla & 18.38 & 92.61 & 11 & Tres Brazos, Centla & 18.23 & 92.60 & 2 \\
\hline Gaviotas, Centro & 17.97 & 92.91 & 10 & Villahermosa, Centro** & 17.98 & 92.92 & 24 \\
\hline
\end{tabular}

Lat=Latitude; Long=Longitude; Alt=Altitude (m); (**) Meteorological observatory.

\section{Model for estimating relative heliophany $(n / N)$}

With the cloudiness monthly average values, the relative heliophany $(n / N)$ was estimated using the equation (1) developed by Tejeda \& Vargas (1996). 


$$
\frac{n}{N}=0.31+0.48 * P Q
$$

Where: $n$ is monthly average daily heliophany (hours), $N$ is monthly average daily astronomical heliophany (hours) and $P Q$ is the complement of the monthly average point cloudiness, calculated with equation (2):

$$
P Q=\frac{D e s p+(0.50 * M e d N u b)}{N u b+M e d N u b+D e s p}
$$

Where: Desp is the average number of clear days in the month, MedNub is the average number of half cloudy days in the month and $N u b$ is the average number of cloudy days in the month.

\section{Model for estimating global solar irradiance}

The monthly average relative solar irradiance $\left(R_{g} / R_{a}\right)$ was calculated following the equation proposed by Tejeda-Martínez et al. (1999). The adaptation of Tejeda-Martínez et $a l$. (1999) for Mexico was to adjust the empirical coefficients " $a$ " and " $b$ " (0.26 and 0.51) shown in equation (3).

$$
R_{g}=\left[0.26 * \operatorname{Cos}(L a t)+0.51 *\left(\frac{n}{N}\right)\right] * R_{a}
$$

Where: $R_{g}$ is the monthly mean daily global solar irradiance $\left(\mathrm{MJ} \mathrm{m}^{-2} \mathrm{~d}^{-1}\right), R_{a}$ is the monthly mean daily extraterrestrial solar irradiance $\left(\mathrm{MJ} \mathrm{m}^{-2} \mathrm{~d}^{-1}\right)$, determined following the procedure proposed by Allen et al. (2006), Lat is the latitude of the meteorological station (degrees), $n$ is the monthly mean daily heliophany (hours) and $N$ is the monthly mean daily astronomical heliophany (hours) according to Allen et al. (2006). The model estimating $R_{g}$ was calibrated using linear regression techniques, similar to the work by Liu et al. (2009).

\section{Calibration and validation of the $\boldsymbol{R}_{\boldsymbol{g}}$ model}

The $R_{g}$ model was calibrated using monthly average data from eight weather stations. The calibrated model was validated using data from the Villahermosa weather station.

\section{Evaluation of model performance}

To evaluate the performance degree of the resulting global solar irradiance model, in addition to the corrected coefficient of determination $\left(R_{c}\right)^{2}$, two additional criteria were used: a) the comparison parameter $(c)$ proposed by Willmott (1981) and b) the efficiency 
index $(E)$ proposed by Nash-Sutcliffe (1970), as criteria to validate the model fit. The comparison parameter $(c)$ of Willmott (1981) is calculated using equation (7):

$$
c=R * d
$$

Where: $c$ is the comparison parameter (dimensionless), $R$ is the correlation coefficient (dimensionless) and $d$ is the Willmott (1981) or concordance index (dimensionless).

The efficiency index $(E)$ or Nash-Sutcliffe (1970) criterion is calculated with equation (9):

$$
E=1.0-\left[\frac{\sum_{i=1}^{N}\left(P_{i}-O_{i}\right)^{2}}{\sum_{i=1}^{N}\left(O_{i}-O_{m}\right)^{2}}\right]
$$

Where: $E$ is the Nash-Sutcliffe (1970) efficiency index, "dimensionless", $P_{i}$ are values estimated or predicted by the model, $O_{i}$ are the observed values, $O_{m}$ the average of the observed values.

The corrected coefficient of determination $\left(R_{c}\right)^{2}$ is calculated with equation (10):

$$
\left(R_{c}\right)^{2}=1-\left(1-R^{2}\right) *\left[\frac{(n-1)}{n-(k+1)}\right]
$$

Where: $R^{2}$ is the coefficient of determination, $n$ is the sample size and; $k$ is the number of independent variables.

The general regression model used was:

$$
\hat{y}=\beta_{0}+\beta_{1} X_{1}+\varepsilon
$$

Where: $\hat{y}$ is the estimated value of " $y$ " for a specific value of $X_{1} . \beta_{0}$ and $\beta 1$ are the parameters of the model, $\varepsilon$ is the error random variable, which accounts for the variability in " $y$ " that cannot be explained by the linear relation between $x$ and $y$.

\section{Spatial distribution of monthly average $\boldsymbol{R}_{g}$}

With the validated global solar irradiance model, the latitude data and the historical monthly average cloudiness values of more than 30 years of record for the rest of the 35 meteorological stations, the corresponding monthly average $R_{g}$ values were estimated for each station. With these values, monthly maps of the spatial distribution of $R_{g}$ were constructed. The maps were prepared using ArcMap GIS software (ESRI, 2004). The maps of the monthly spatial distribution of $R_{g}$ were constructed at a scale of 1:250 000 
using the Kriging Universal spatial interpolation method, included in the ArcMap 10.2 GIS software.

\section{RESULTS AND DISCUSSION}

Table 2 shows the regression equations, their corrected coefficient of determination $\left(R_{c}\right)^{2}$ and the resulting standard error (SEE), for the eight stations used to fit the model proposed by Tejeda-Martínez et al. (1999) with observed monthly average global solar irradiance data. Reviewing the corrected determination coefficients $\left(R_{c}\right)^{2}$ (Table 2), it can be observed that there is a good fit between the estimated values of $R_{g}$ by the model and the observed ones. The $\left(R_{c}\right)^{2}$ values ranged from 0.85 to 0.89 , which are alike to the values reported by Liu et al. (2009). The standard error values (SEE) shown in Table 2 are small, given the used units, and imply little scattering of the data (Figure 1), which shows the plot resulting from comparing all the observed monthly average $R_{g}$ data from the eight automatic stations (AMS's), with all the estimated $R_{g}$ data for the eight ordinary climatological stations.

The resulting equation $y=1.0366 * X$ was used to estimate the monthly average $R_{g}$ for the Villahermosa station to validate and evaluate the goodness and degree of performance of the model. The estimated $R_{g}$ values obtained with the model were compared with those observed in the AMS of Villahermosa, Tabasco, using regression analysis. The resulting equation was as follows:

$$
y=1.0326 * x ; \quad\left(R_{c}^{2}\right)=0.87 ; \quad S E E=0.53
$$

$\left(R_{c}{ }^{2}\right)=$ corrected coefficient of determination estimated with equation 10 .

Table 2. Regression equations of the relation between the estimated monthly average global solar irradiance (equation 3) and that observed at eight meteorological stations at Tabasco, Mexico.

\begin{tabular}{|c|c|c|c|}
\hline Meteorological station & $\begin{array}{c}\text { Regression } \\
\text { equation }\end{array}$ & $\left(\mathbf{R}_{\mathbf{c}}\right)^{2}$ & SEE \\
\hline Boca de Cerro, Tenosique & $y=0.9691 * X$ & 0.87 & 0.26 \\
\hline Dos Patrias, Tacotalpa & $y=1.0660 * X$ & 0.89 & 0.36 \\
\hline Emiliano Zapata, Emiliano Zapata & $y=1.0629 * X$ & 0.85 & 0.57 \\
\hline Huimanguillo, Huimanguillo & $y=0.0836 * X$ & 0.88 & 0.38 \\
\hline Paraíso, Paraíso & $y=1.0172 * X$ & 0.85 & 0.19 \\
\hline Pueblo Nuevo, Centro & $y=1.0486 * X$ & 0.86 & 0.53 \\
\hline San Pedro, Balancán & $y=1.0644 * X$ & 0.85 & 0.31 \\
\hline Tres Brazos, Cientla & $y=0.9813 * X$ & 0.86 & 0.72 \\
\hline
\end{tabular}

The validation of the Tejeda-Martínez et al. (1999) model resulted in equation (12), which allows a reliable model to estimate the $R_{g}$ for the entire state of Tabasco from 
cloudiness data. Therefore, the regression equation shown in Figure 1 was used to estimate the $R_{g}$ for all the months of the rest of the 35 selected stations (26 stations), from which only cloudiness data were available.

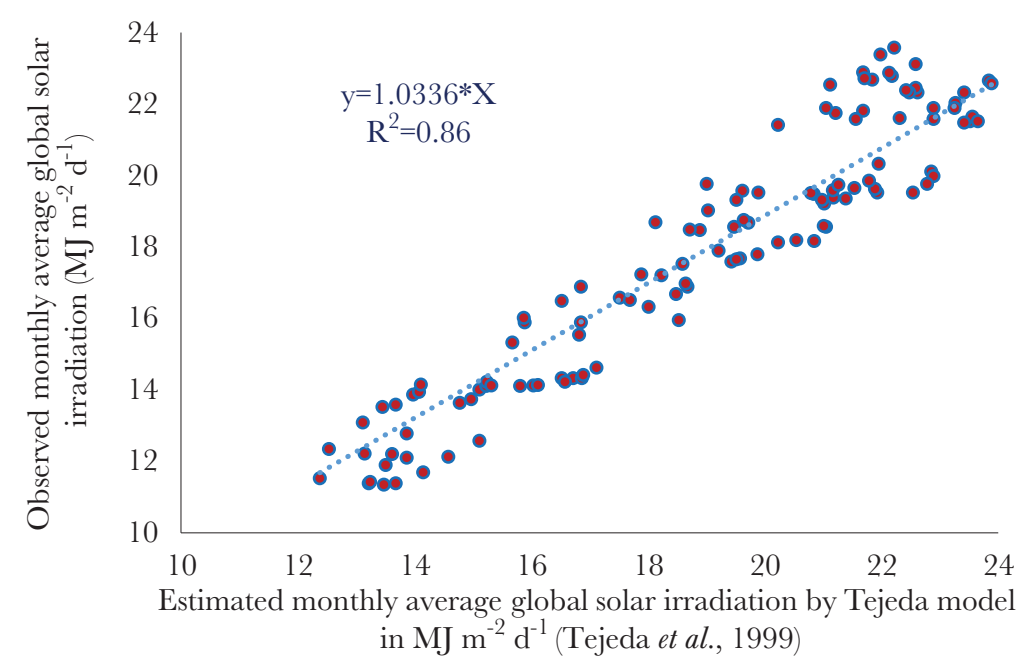

Figure 1. Relationship between the estimated and observed monthly average global solar irradiance values for the complete set of eigh stations.

\section{Evaluation of the degree of model performance}

When determining the values of the Willmott comparison parameter $(c)(1981)$ and the Nash-Sutcliffe (1970) efficiency index $(E)$, between the estimated and observed values of the $\operatorname{Rg}$ for the Villahermosa station, the values were: $c=0.89$ and $E=0.99$. With $c>0.85$, the degree of performance and fit of the model is rated as optimal, and with $E>0.81$ the rating is excellent.

\section{Spatial distribution of global solar irradiation}

Due to the agricultural importance of the seasons (north winds, dry and rainy seasons) according to the precipitation regime in Tabasco, the analysis of the spatial distribution of irradiation was carried out according to these seasons. Figure 2 shows the spatial distribution of $R_{g}$ for November, December, January and February, the period of north winds. These maps show that the lowest $R_{g}$ value $\left(12 \mathrm{MJ} \mathrm{m}^{-2} \mathrm{~d}^{-1}\right)$ occurs during December and is the highest in February $\left(18 \mathrm{MJ} \mathrm{m}{ }^{-2} \mathrm{~d}^{-1}\right)$. The estimated $R_{g}$ values at the monthly average level are similar to those reported by the Geophysics Institute of the UNAM (UNAM, 2014); with the difference that the maps made in this research show greater detail, due to its greater number of meteorological stations.

During the northern winds season, the lowest global solar irradiation is received during the year. These low $R_{g}$ values are mainly due to high cloudiness and prolonged periods of precipitation (IMTA, 2009), as well as daytime heliophony, which decreases global solar irradiance (De Jong \& Stewart, 1993). 
During November, December and February, a similar distribution pattern of $R_{g}$ is observed, although with different values. The areas with the highest global solar irradiation incidence during the northern wind season, which occur in February and include parts of the municipalities of Tacotalpa, Teapa and Jalapa in the Sierra subregion; in the area bordering the state of Chiapas in the municipality of Tenosique in the Los Ríos subregion; and in the coastal strip of the municipality of Centla, in the Pantanos subregion. This may be because in February there is a 14-day period (between the 9th and 23rd) with a water deficit (Ruíz-Álvarez et al., 2012) as well as clouds absence.

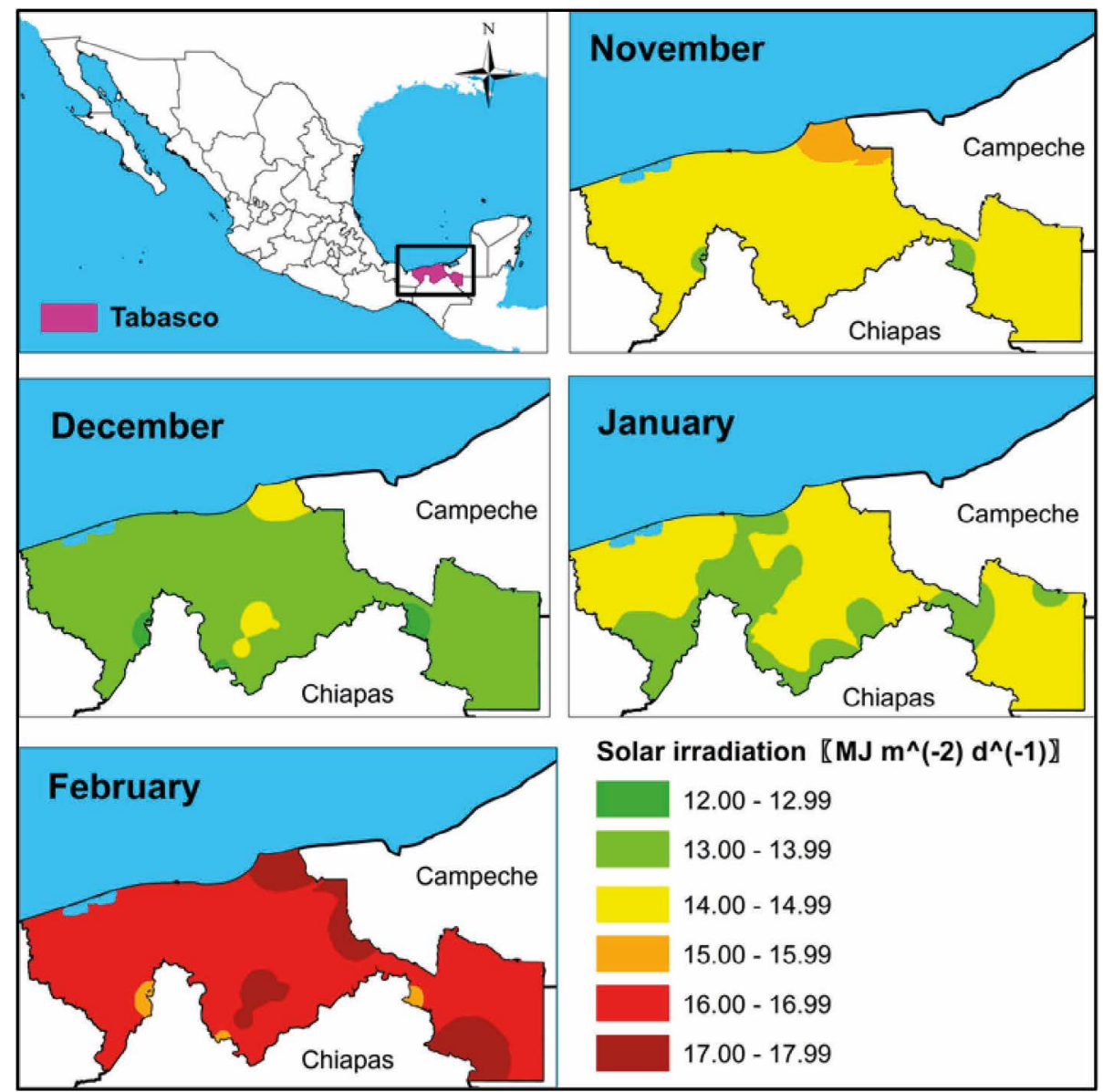

Figure 2. Average global solar irradiance for november to february, corresponding to the period of north winds.

The maps in Figure 3 correspond to the dry season when the highest global solar irradiation of the year occurs. During March, there is a transition from the northeast to the dry season, which is why the value of irradiation increases due to the greater number of clear days, as well as the decrease in precipitation, compared to the northeast season. The largest area of the state is covered by the irradiation interval of 19.00-19.99 $\mathrm{MJ} \mathrm{m}^{-2}$ $\mathrm{d}^{-1}$ (Chontalpa and Centro subregions) and the highest irradiation interval of 20:00- 
21:00 $\mathrm{MJ} \mathrm{m}^{-2} \mathrm{~d}^{-1}$, located in the municipalities of Centla, Jonuta, Emiliano Zapata, Balancán and Tenosique, which make up the lower basin of the Usumacinta River.

April and May have the highest global solar irradiation of the year. This is because these are the months with the greatest water deficit (Ruíz-Álvarez et al., 2012), as well as the lowest cloud cover (IMTA, 2009). In April, the largest irradiation interval (22.0$22.99 \mathrm{MJ} \mathrm{m}^{-2} \mathrm{~d}^{-1}$ ) covers most of the state, and in May the same interval covers almost the entire state. The highest irradiance in May is in a few small areas in the subregions: Chontalpa (municipalities: Cardenas and Huimanguillo), Pantanos (municipalities: Centla, on the coastal strip and Jonuta, an area bordering the state of Campeche) and Ríos (municipality: Tenosique, the area bordering the state of Chiapas).

Figure 4 shows the $R_{g}$ spatial distribution during June, July, August, September and October, which are the rainy season. The maximum $R_{g}$ begins to decrease from June $\left(21.99 \mathrm{MJ} \mathrm{m}^{-2} \mathrm{~d}^{-1}\right)$ to October (17.99 $\left.\mathrm{MJ} 17.99 \mathrm{MJ} \mathrm{m}^{-2} \mathrm{~d}^{-1}\right)$. The observed maximum value in June is because, until the middle of the month, there still are clear days and the longest day length throughout the year. Likewise, for June the Rg interval $>22.00 \mathrm{MJ} \mathrm{m}^{-2}$ $\mathrm{d}^{-1}$ distributes in the coastal strip of Centla municipality; however, this interval disappears by July to reappear again in August and September. In October, the interval of 16.00$16.99 \mathrm{MJ} \mathrm{m}^{-2} \mathrm{~d}^{-1}$ is predominant in most of the state of Tabasco.

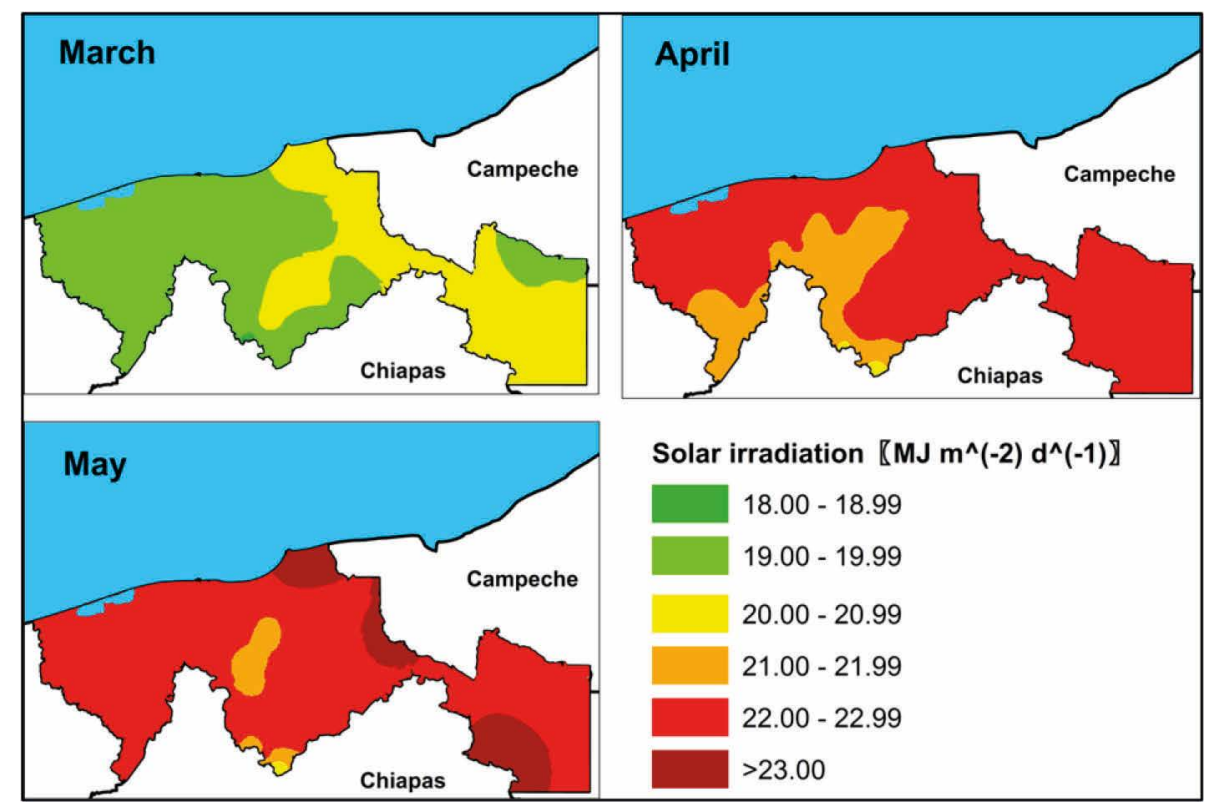

Figure 3. Average global solar irradiance for march, april and may, during the dry season.

An agronomic interpretation of global irradiance variation in Tabasco imposes biophysical limits on crop growth and development rate (van Ittersum et al., 2013), given there is a high correlation between global irradiance and net biomass production (De Wit, 1959). For example, the energy conversion efficiency in maize plants without water stress is 1.2 to $1.6 \mathrm{~g} \mathrm{MJ}^{-1} \mathrm{~m}^{-2}$ of intercepted solar radiation (Muchow, 1994), 
for sorghum is 0.66 to $1.39 \mathrm{~g} \mathrm{MJ}^{-1} \mathrm{~m}^{-2}$ (Hernández-Cordova \& Soto-Carreño, 2013). Considering the energy conversion data for maize and sorghum, it is expected that the highest net biomass yields are obtained during the dry season for maize and sorghum, because C4 plants require high temperature and light intensity. However, this would only be possible if irrigation was to be available since rainfall during the dry season is scarce and insufficient.

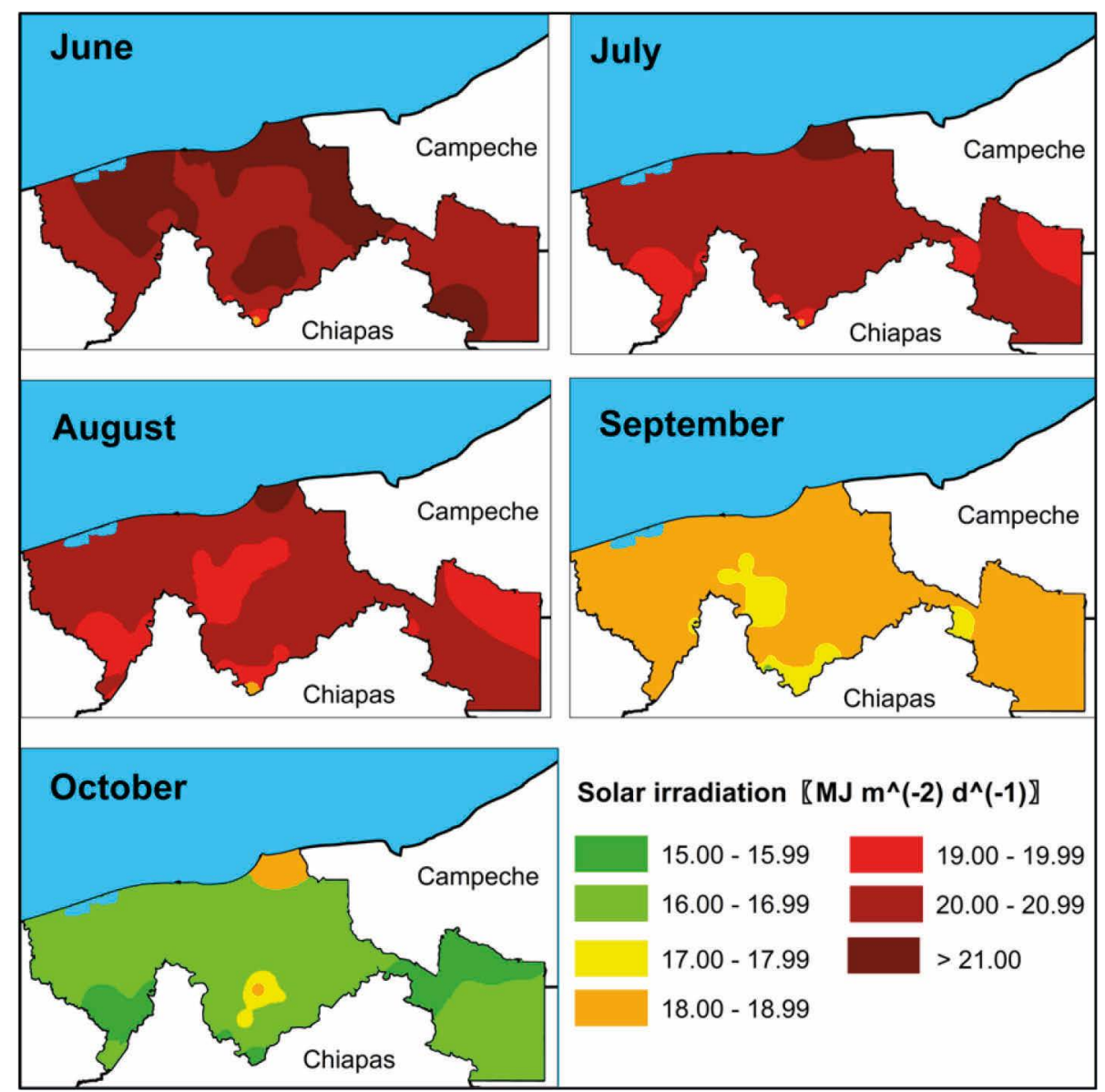

Figure 4. Average global solar irradiance for june, july, august, september and october, corresponding to the rainy season.

\section{GONGLUSIONS}

The monthly $R_{g}$ average values estimated with the proposed model from observed daily $R_{g}$ data and percentage of cloudy days (cloudiness) reported a good fit. The spatial distribution of the global monthly average $R_{g}$ irradiation in the three climatic periods spatially varies throughout the year. During the north windy season, the minimum $R_{g}$ values occur in December are the highest in February, while in the dry season the minimum $R_{g}$ occurs during March and the maximum in May. In the rainy season, the $R_{g}$ incidence gradually decreased from June to August. 


\section{REFERENGES}

Allen, R.G., Pereira, L.S., Raes, D. \& Smith, M. (2006). Evapotranspiración del cultivo. Guías para la determinación de los requerimientos de agua de los cultivos. Estudio FAO riego y drenaje No 56. Disponible; http://www.fao.org/3/a-x0490s.pdf.

Bouchouicha, K., Hassan, M.A., Bailek, N., \& Aoun, N. (2019). Estimating the global solar irradiation and optimizing the error estimates under Algerian desert climate. Renewable Energy, 139: pp.844-858. doi: 10.1016/j.renene.2019.02.071

De Jong, R., \& Stewart, D.W. (1993). Estimating global solar radiation from common meteorological observations in western Canada. Journal of Plant Science, 73(2): pp.509-518. Doi: 10.4141/cjps93-068.

De Wit, C.T. (1959). Potential photosynthesis of crop surfaces. Journal of Agricultural Science, 7(2): pp.141-149. Doi: 10.18174/njas.v7i2.17686.

ESRI. (Environmental System Research Institute). 2004. ArcGIS. 9.3. Getting Started with ArcGIS. USA.

Hernández-Cordova, N., \& Soto-Carreño, F. (2013). Determinación de índices de eficiencia en los cultivos de maíz y sorgo establecidos en diferentes fechas de siembra y su influencia sobre el rendimiento. Cultivos Tropicales, 34(2): pp.24-29.

IMTA. (Instituto Mexicano de Tecnología del Agua). 2009. ERIC III: Extractor Rápido de Información Climatológica v.2. CD, 28 p.

Liu, X., Mei, X., Li, Y., Zhang, Y., Wang, Q., Jensen, J. R., \& Porter, J.R. (2009). Calibration of the Ångström-Prescott coefficients (a, b) under different time scales and their impacts in estimating global solar radiation in the Yellow River basin. Agricultural Forest Meteorology, 149(3-4): pp.697-710. Doi: 10.1016/j.agrformet.2008.10.027.

Muchow, R.C. (1994). Effect of nitrogen on yield determination in irrigated maize in tropical and subtropical environments. Field Crops Research, 38(1):pp.1-13. Doi:10.1016/0378-4290(94)90027-2.

Nash, J.E., \& Sutcliffe, J.V. (1970). River flow forecasting through conceptual models, part I. A discussion of principles. Journal of Hydrology, 10(3): pp.282-290. Doi: 10.1016/0022-1694(70)90255-6.

Quej, V.H., Almorox, J., Ibrakhimov, M., \& Saito, L. (2016). Empirical models for estimating daily global solar radiation in Yucatán Peninsula, Mexico. Energy Conversion and Management, 110: 448-456. Doi:10.1016/j.enconman.2015.12.050.

Ruíz-Álvarez, O., Arteaga-Ramírez, R., Vázquez-Peña, M.A., \& López-López, R. (2012). Inicio de la estación de crecimiento y periodos secos en Tabasco, México. Tecnología y Ciencias del Agua, 3(2): pp.85-102.

SMN. (Servicio Meteorológico Nacional). 2016. Disponible en: http://smn.cna.gob.mx/emas/. [Última consulta 18 de agosto de 2019].

Tejeda-Martínez, A., \& Vargas, A. (1996). A correlation between visual observations and instrumental records of cloudiness in Mexico. Geofísica Internacional, 35(4): pp.421-424.

UNAM. (Universidad Nacional Autónoma de México). 2014. Atlas Solar Mensual. Instituto de Geofísica, UNAM. Disponible en: www.geofisica. unam.mx/radiacion_solar/atlas.php.

Willmott, C.J. (1981). On the validation of models. Journal Physical Geography, 2(2): pp.184-194. Doi: 10.1080/02723646.1981.10642213.

van Ittersum, M.K., Casman, K.G., Grassini, P., Wolf, J., Tittonell, P., \& Hochman, Z. (2013). Yield gap analysis with local to global relevance-a review. Field Crops Res, 143: pp.4-17. Doi:10.1016/j.fcr.2012.09.009. 